\title{
KUALITAS LAYANAN WISATA MEDIS YANG MEMPENGARUHI KEPUASAN DAN LOYALITAS WISATAWAN MANCANEGARA DI BALI
}

\author{
Yudha Eka Nugraha \\ Universitas Udayana \\ Email: yudhaekanugraha@gmail.com \\ Syamsul Alam Paturusi \\ Universitas Udayana \\ Email: syamsul@unud.ac.id \\ NMS Wijaya \\ Universitas Udayana \\ Email: mdsofiawij@gmail.com
}

\begin{abstract}
Medical Tourism is a potential sector to develop in Bali. Medical clinics offer various medical services treatment to attract tourists. The clinics must have an excellent quality of standard services to get customers satisfaction. The aim of this study is to analyze the influence of the medical services quality on tourist satisfaction and tourist loyalty in Radiance Clinic Bali. They were about 200 respondents and selected using accidental sampling technique. The analysis uses Structural Equation Model (SEM), calculated with AMOS program. The result of research examines that service quality is a main variable with significance effects on the satisfaction and loyalty of tourists' customers in Bali. Results of the research indicated that there is direct effect between service quality to satisfaction and satisfaction to loyalty. On the other hand, indirect effect happens between service quality to loyalty.
\end{abstract}

Keywords: Service Quality, Tourist Satisfaction, Tourist Loyalty

\section{Pendahuluan}

Kemunculan wisata medis yang mendatangkan keuntungan jutaan dollar bagi negara-negara maju seperti Korea dan Amerika (Horowitz dkk., 2007) membuat Pemerintah Indonesia melakukan terobosan baru dengan menjadikan Bali sebagai 
lokasi utama untuk wisata medis Indonesia. Sebagai lokasi favorit untuk berwisata di Indonesia, jumlah kunjungan wisatawan mancanegara ke Bali selalu meningkat dari tahun ketahun. Menurut data yang dikumpulkan oleh Dinas Pariwisata Provinsi Bali tahun 2018, selama lima tahun terakhir, rata-rata kenaikan mencapai 15,7\% dari tahun 2013 sampai 2017. Kenaikan paling signifikan terjadi pada tahun 2016 ke 2017 dengan jumlah kenaikan wisatawan berjumlah 4,92 juta jiwa dengan persentasi kenaikan 23,14\%. Kenaikan jumlah wisatawan mancanegara paling banyak berasal dari Tiongkok dengan jumlah kunjungan sebesar 1.452.971 jiwa dan Australia dengan jumlah kunjungan 1.198 .033 jiwa (Kementerian Pariwisata Indonesia, 2017).

Kemajuan tersebut terjadi karena beberapa faktor seperti; suksesnya strategi promosi pariwisata, kemunculan pariwisata alternatif, dan kesadaran pemerintah suatu negara (Singh, 2014). Salah satu kemunculan pariwisata alternatif yang sedang berkembang dalam dunia akademis dan praktis di industri pariwisata adalah pariwisata medis. (Connell, 2006) dan (Smith dkk., 2008) menyebutkan pelayanan kesehatan sedang diminati oleh wisatawan saat ini. Lebih dari 130 negara didunia saling berkompetisi untuk merebut bagian terbesar dalam memenangkan share bisnis global dalam bidang pariwisata medis. Saat ini diestimasikan bahwa dalam skala global, pariwisata medis mendatangkan keuntungan 40 miliar US dollar dengan pertumbuhan rata-rata pertahun 20\% (Singh, 2014).

Wisatawan medis pada umumnya merupakan penduduk yang berasal dari negara maju seperti USA, UE, Canada, dan Australia, yang membutuhkan layanan medis ke negara berkembang seperti Bangkok, Singapura, New Delhi, dan Seoul. Wisatawan medis melakukan perjalanan untuk mendapat keuntungan layanan medis dengan harga yang terjangkau, kompetensi dokter yang lebih baik, dan waktu lebih cepat untuk menerima layanan medis (Debata 2013), serta meningkatkan keseimbangan perawatan tubuh dan jiwa melalui layanan medis (Carrera dan Bridges 2006, Connell 2006, Garcia-Altes 2005).

349 JUMPA Volume 05, Nomor 02, Januari 2019 
Menurut (Singh, 2014) wisata medis atau medical tourism diartikan sebagai perjalanan secara eksplisit untuk mendapatkan treatment medis di negara asing. Pasien-pasien dalam kategori medical tourism mencari kualitas pelayanan spesifik yang ditawarkan oleh rumah sakit atau lembaga kesehatan di negara tujuan. Salah satu lokasi layanan medis favorit wisatawan mancanegara berada di daerah Kuta yaitu Klinik Radiance. Klinik ini berbasis pada pelayanan medis dengan perawatan wajah dan tubuh. Klinik ini dipilih berdasarkan pada alasan karena beberapa hal, yakni: peningkatan jumlah pasien wisatawan mancanegara sebangak 130\% setiap tahun dalam lima tahun terakhir, 90\% pasien klinik merupakan wisatawan mancanegara, lokasi klinik berada di daerah Kuta sebagai lokasi jantung pariwisata Bali, dan merupakan klinik paling ramai dibandingkan dengan klinik perawatan wajah dan tubuh sejenis di Bali.

Semenjak berdiri pada tahun 2012, jumlah pasien Klinik Radiance selalu meningkat sebanyak rata-rata $130 \%$. Saat ini, tercatat 12.750 wisatawan mancanegara telah menjadi pasien Klinik Radiance baik pasien baru maupun pasien setia. Penambahan yang paling signifikan terjadi antara tahun 2016 ke tahun 2017 dengan peningkatan 3.800 pasien wisatawan mancanegara. Jumlah pasien yang semakin banyak menunjukkan bahwa pasien klinik merasakan kepuasan ketika melakukan layanan medis di Klinik Radiance. Kepuasan wisatawan merupakan kunci dalam meningkatkan loyalitas wisatawan (Debata, 2013). Tingkat kepuasan yang tinggi akan mendatangkan beberapa manfaat bagi lembaga kesehatan yakni loyalitas, dan peningkatan reputasi pada bisnis lembaga (Fornell, 1992, dalam Aryani, 2010). Penelitian terdahulu menyebutkan, kepuasan wisatawan dapat berada ditengah dan antara kualitas layanan dan loyalitas wisatawan sehingga secara tidak langsung memberikan pengaruh melalui konstruk kepuasan (Caruana, 2002, Pidada, 2018).

Dewasa ini, tingkat persaingan usaha layanan kesehatan semakin kompetitif. Hal ini berdampak pada fenomena dimana wisatawan medis menemui berbagai produk sejenis, dengan harga dan kualitas yang beragam. Hal ini menyebabkan 
wisatawan akan selalu mencari nilai manfaat tertinggi dalam beberapa produk jasa dan layanan (Kotler, 2005). Kualitas yang rendah akan berdampak pada ketidakpuasan wisatawan, karena wisatawan yang kecewa paling tidak akan menyebarkannya ke 15 orang terdekat (Aryani, 2010, Wijayanti 2017). Hal ini berdampak pada kecenderungan wisatawan memilih kompetitor (Lupiyoadi., dkk, 2006).

Pertumbuhan lembaga kesehatan di Bali menunjukkan perkembangan pesat, hal ini terlihat dari jumlah klinik layanan kesehatan di Bali yang bertambah dua kali lipat setiap tahunnya. Hal tersebut menunjukkan peluang besar bisnis pariwisata medis di Bali. Peluang ini kemudian menjadi menarik untuk diteliti mengenai hubungan antara kualitas layanan medis, kepuasan wisatawan mancanegara dan loyalitas wisatawan mancanegara melalui Klinik Radiance, Kuta Bali. Berdasarkan fenomena tersebut, artikel ini secara umum bertujuan untuk mengetahui pengaruh yang terbentuk antara kualitas layanan, kepuasan, serta loyalitas wisatawan mancanegara. Secara khusus artikel ini mencoba membahas mengenai (1) Pengaruh antara kualitas pelayanan medis dan kepuasan wisatawan, (2) Pengaruh antara kepuasan wisatawan mancanegara dan loyalitas wisatawan, serta (3) Pengaruh kualitas layanan dan loyalitas wisatawan mancanegara.

\section{Landasan Teori dan Konsep}

\section{Teori}

Sehubungan dengan pembahasan dalam latar belakang dan permasalahan, pada bagian ini akan dipaparkan tiga teori yang dapat menjelaskan tiga variabel laten dalam artikel ini yaitu: variabel kualitas layanan, variabel kepuasan wisatawan, dan variabel loyalitas wisatawan. Adapun penjelasan teori yang menjadi dasar dalam artikel ini adalah sebagai berikut: 


\section{Kualitas Layanan}

Metode SERVQUAL (Service Quality) mewakili kualitas layanan sebagai gap antara ekspektasi konsumen mengenai layanan yang ditawarkan dengan persepsi konsumen terhadap layanan yang diterima, nantinya akan dibutuhkan responden untuk menjawab pertanyaan baik dari ekspektasi dan persepsinya Parasuraman et al., 1988. Penggunaan perceived merupakan lawan dari actual service membuat SERVQUAL mengukur perilaku yang berhubungan dengan kepuasan (Parasuraman dkk., 1988). Perbedaan antara ekspektasi dan persepsi merupakan gap yang menjadi determinan persepsi konsumen terhadap kualitas layanan.(Kumar dkk., 2009, h. 214).

Penemuan terbaru mengenai konsep kualitas pelayanan dilakukan oleh Debata, 2013. Penemuan ini menyebutkan bahwa dalam kualitas pelayanan terdapat 8 indikator yang mempengaruhi kepuasan wisatawan ketika merasakan pelayanan medis. Kedelapan indikator tersebut adalah: (1) Accesibility, (2) Treatment Satisfaction, (3) Courtesy, (4) Physical Environment Features, (5) Technical Quality of Care, (6) Promptness, (7) Facility Premises (8) Finance Factors for Medical Services.

Kedelapan indikator tersebut kemudian dipilih karena paling relevan dengan artikel ini. Atas dasar bahwa indikator tersebut merupakan penemuan terbaru mengenai indikator penyusun kualitas pelayanan dalam menentukan kepuasan wisatawan dalam menerima layanan medis terutama dalam artikel ini adalah wisatawan asing yang menikmati layanan medis di Klinik Radiance, Kuta, Bali.

\section{Kepuasan Wisatawan}

Teori yang dipilih untuk menjelaskan variabel kepuasan wisatawan adalah teroi pengukuran kepuasan menurut Baker (2000) dan Bigne (2001). Pengukuran kepuasan menurut Baker dan Crompton (2000) dan Bigne dkk. (2001) menjelaskan bahwa terdapat lima indikator utama pengukur kepuasan yaitu; kepuasan nilai, kepuasan aktivitas, kepuasan memilih, kepuasan pengalaman, dan kepuasan 
keseluruhan. Bila dihubungkan dengan artikel ini, maka indicator tersebut paling relevan karena penelitian tersebut spesifik membahas mengenai konteks kepuasan dari sisi wisatawan yang sesuai dengan objek dalam penelitian ini yaitu wisatawan asing.

\section{Loyalitas Wisatawan}

Menurut Kozak dan Rimington (1999), kualitas pelayanan sangat penting untuk mengukur tingkat kepuasan keseluruhan wisatawan sehingga memunculkan intensi untuk datang kembali untuk mencari layanan tersebut (loyalitas). Penelitian terbaru menurut Debata 2013 menunjukkan bahwa loyalitas wisatawan medis terbagi menjadi tiga, yakni: Behavior Loyalty, Attitudinal Loyalty, dan Cognitive Loyalty. Lebih lanjut, didalam ketiga faktor pembentuk loyalitas menurut Debata (2013) ini, terbagi lagi menjadi lima indikator yang akan digunakan dalam penelitian ini, yaitu: keinginan mencoba layanan lain, keinginan merekomendasikan, keinginan berlangganan, keinginan mengutamakan layanan, dan keinginan untuk kembali. Indikator ini akan menjadi acuan artikel ini.

\section{Metode Penelitian}

Artikel ini menggunakan metode penelitian kuantitatif dengan observasi langsung ke lapangan, studi dokumentasi, dan menyebarkan kuisioner. Penelitian dilakukan di Klinik Radiance di Kuta, Bali karena didasarkan atas beberapa hal: (1) 90\% pasien merupakan wisatawan mancanegara, (2) peningkatan pasien asing yang signifikan tahun 2012-2017, (3) 500 wisatawan perbulan melakukan tindakan medis seperti: injeksi vitamin C, injeksi filler, peremajaan kulit dan anti aging, dan tindakan estetik lainnya. (4) berlokasi di jantung pariwisata Bali, yaitu Kuta, (5) Belum pernah ada penelitian sejenis yang memilih topik estetik medis dalam payung besar wisata medis. Penelitian ini dilakukan sejak September 2017 sampai April 2018. 
Instrumen yang dipilih untuk artikel ini yaitu kuisioner. Berdasarkan data kunjungan pasien wisatawan mancanegara di Klinik Radiance, rata-rata kunjungan wisatawan mancanegara sebanyak 300-500 perbulan. Sesuai dengan kebutuhan AMOS, maka responden yang dibutuhkan adalah minimal berjumlah 200 (Hair dkk., 2010) responden, dikumpulkan dengan teknik non probabilita sampling.

Berikut adalah definisi konseptual ketiga variabel laten, dijelaskan lebih lanjut dalam table sebagai berikut;

Tabel 1. Konstruk Kualitas Layanan Medis

\begin{tabular}{|c|c|c|c|}
\hline Konstruk Laten & Indikator & Penjelasan Indikator & Kode \\
\hline \multirow[t]{7}{*}{$\begin{array}{l}\text { Kualitas } \\
\text { Pelayanan Medis }\end{array}$} & $\begin{array}{l}\text { Aksesibilititas } \\
\text { (Accessibility) }\end{array}$ & $\begin{array}{l}\text { Ketersediaan contact center yang bersedia } \\
\text { memandu wisatawan sesuai } \\
\text { kebutuhannya }\end{array}$ & SQ1 \\
\hline & $\begin{array}{l}\text { Standar Layanan } \\
\text { (Treatment Standard) }\end{array}$ & $\begin{array}{l}\text { Sikap positif seluruh karyawan klinik } \\
\text { untuk membangun emosi yang baik }\end{array}$ & SQ2 \\
\hline & $\begin{array}{l}\text { Keramahan } \\
\text { (Courtesy) }\end{array}$ & $\begin{array}{l}\text { Karyawan klinik memberikan perhatian } \\
\text { sepenuhnya kepada pasien wisatawan } \\
\text { mancanegara }\end{array}$ & SQ3 \\
\hline & $\begin{array}{l}\text { Lingkungan Fisik } \\
\text { (Physical Environment } \\
\text { Features) }\end{array}$ & $\begin{array}{l}\text { Keamanan selama melakukan perawatan } \\
\text { di Klinik Radiance dan Kenyamanan } \\
\text { selama berada di Klinik Radiance mulai } \\
\text { dari datang sampai dengan selesai } \\
\text { melakukan perawatan medis }\end{array}$ & SQ4 \\
\hline & $\begin{array}{l}\text { Kompetensi Kualitas } \\
\text { (Technical Quality of } \\
\text { Care) }\end{array}$ & $\begin{array}{l}\text { Akreditasi klinik yang diakui secara } \\
\text { internasional }\end{array}$ & SQ5 \\
\hline & $\begin{array}{l}\text { Ketepatan Waktu } \\
\text { (Promptness) }\end{array}$ & $\begin{array}{l}\text { Kemampuan dokter dalam melakukan } \\
\text { diagnosa secara tepat dan dalam waktu } \\
\text { yang sesingkat-singkatnya }\end{array}$ & SQ6 \\
\hline & $\begin{array}{l}\text { Fasilitas (Facility } \\
\text { Premises) }\end{array}$ & $\begin{array}{l}\text { Kemudahan dalam melakukan } \\
\text { pembayaran (bisa melalui tunai atau }\end{array}$ & SQ7 \\
\hline
\end{tabular}




\begin{tabular}{|l|l|l|l|}
\hline & menggunakan kartu debit) & \\
\hline & $\begin{array}{l}\text { Faktor Finansial } \\
\text { (Finance Factors for } \\
\text { Medical Services) }\end{array}$ & $\begin{array}{l}\text { Harga perawatan medis yang terjangkau } \\
\text { bagi wisatawan mancanegara }\end{array}$ & SQ8 \\
\hline
\end{tabular}

Sumber: Debata, (2013)

Tabel 2. Konstruk Kepuasan Wisatawan

\begin{tabular}{|c|c|c|c|}
\hline Konstruk Laten & Indikator & Penjelasan Indikator & Kode \\
\hline \multirow[t]{5}{*}{$\begin{array}{l}\text { Kepuasan } \\
\text { Wisatawan } \\
\text { Mancanegara }\end{array}$} & Kepuasan Nilai & $\begin{array}{l}\text { Merasa senang selama berada di Klinik } \\
\text { Radiance sehingga akan memberikan } \\
\text { testimoni positif kepada kerabatnya }\end{array}$ & SAT1 \\
\hline & Kepuasan Aktivitas & $\begin{array}{l}\text { Merasa senang dengan jenis perawatan } \\
\text { yang ditawarkan oleh klinik, } \\
\text { kelengkapan jenis perawatan medis }\end{array}$ & SAT2 \\
\hline & Kepuasan Memilih & $\begin{array}{l}\text { Pilihan dalam memilih Klinik Radiance } \\
\text { adalah pilihan yang tepat }\end{array}$ & SAT3 \\
\hline & Kepuasan Pengalaman & $\begin{array}{l}\text { Merasakan Pengalaman menyenangkan } \\
\text { selama mendapatkan layanan di Klinik } \\
\text { Radiance. Seluruh jenis perawatan } \\
\text { medis mulai dari awal perawatan } \\
\text { sampai selesai }\end{array}$ & SAT4 \\
\hline & $\begin{array}{l}\text { Kepuasan Secara } \\
\text { Keseluruhan }\end{array}$ & $\begin{array}{l}\text { Secara Keseluruhan Puas dengan } \\
\text { layanan perawatan medis di Klinik } \\
\text { Radiance }\end{array}$ & SAT5 \\
\hline
\end{tabular}

Sumber: Baker, Crompton (2000) dan Bigne et al (2001) 
Tabel 3. Konstruk Loyalitas Wisatawan

\begin{tabular}{|c|c|c|c|}
\hline Konstruk Laten & Indikator & Penjelasan Indikator & Kode \\
\hline \multirow{5}{*}{$\begin{array}{l}\text { Loyalitas } \\
\text { Wisatawan } \\
\text { Mancanegara }\end{array}$} & \multirow[t]{2}{*}{ Behavioral Loyalty } & $\begin{array}{l}\text { Keinginan untuk mau mencoba } \\
\text { layanan lain di Klinik Radiance }\end{array}$ & LOY1 \\
\hline & & $\begin{array}{l}\text { Keinginan untuk berlangganan } \\
\text { dengan Klinik Radiance }\end{array}$ & LOY2 \\
\hline & Attitudinal Loyalty & $\begin{array}{l}\text { Keinginan untuk } \\
\text { merekomendasikan klinik } \\
\text { Radiance kepada kolega }\end{array}$ & LOY3 \\
\hline & \multirow[t]{2}{*}{ Cognitive Loyalty } & $\begin{array}{l}\text { Keinginan menjadikan klinik } \\
\text { Radiance sebagai pilihan utama }\end{array}$ & LOY4 \\
\hline & & $\begin{array}{l}\text { Keinginan untuk kembali lagi } \\
\text { menggunakan layanan medis } \\
\text { oleh Klinik Radiance }\end{array}$ & LOY5 \\
\hline
\end{tabular}

Sumber: Debata, (2013)

\section{Hasil Penelitian}

\section{Karakteristik Responden}

Gambaran mengenai pasien wisatawan medis dalam artikel ini diklasifikasikan berdasarkan pada jenis kelamin, usia, Negara asal, pekerjaan, tujuan mengunjungi Bali, dan frekuensi mengunjungi Klinik Radiance. Berikut pemaparan lebih lanjut mengenai 200 pasien wisatawan medis.

\section{Jenis Kelamin}

Berdasarkan data responden, dari 200 wisatawan pada komposisi jenis kelamin menunjukkan bahwa mayoritas responden berjenis kelamin perempuan dengan persentase sebesar $86,79 \%$ dan sisanya $13,21 \%$ adalah wisatawan laki-laki.

\section{Usia}

Berdasarkan hasil penyebaran kuisioner, mayoritas responden berusia diatas 40 tahun berjumlah 147 wisatawan mancanegara dari 200 responden atau sebesar 
69,34\%, sedangkan mereka yang berusia dibawah 40 tahun berjumlah 65 wisatawan atau setara dengan $30,66 \%$.

\section{Negara Asal}

Wisatawan mancanegara dengan latar belakang kewarganegaraan yang berbeda. Data mengenai Negara asal akan menjadi dasar darimana wisatawan mancanegara yang paling meminati layanan medis di Bali.

Berdasarkan hasil olahan data statistik deskriptif 200 sampel menurut Negara asal, wisatawan mancanegara yang paling banyak menggunakan layanan medis di Klinik Radiance berasal dari Australia, berjumlah 163 orang atau setara dengan $76,89 \%$.

Urutan kedua dipegang oleh wisatawan Perancis yang berjumlah 17 orang atau setara dengan 8,02\%, urutan ketiga oleh wisatawan Inggris (British), Jepang, Selandia Baru, dan Amerika Serikat.

\section{Pekerjaan}

Hasil olahan data menunjukkan bahwa dari 200 wisatawan medis, sebanyak 158 wisatawan atau setara dengan 74,53\% merupakan professional dari berbagai bidang. Urutan kedua dipegang oleh wisatawan yang berprofesi sebagai bisnisman berjumlah 35 orang atau setara dengan 16,51\%, dan pensiunan berjumlah 19 wisatawan atau setara dengan $8,96 \%$.

\section{Tujuan Kunjungan ke Bali}

Berdasarkan hasil olahan statistik deskriptif AMOS versi 24, sebanyak 91,98\% dari 200 wisatawan mancanegara melakukan kunjungan ke Bali untuk aktivitas liburan, sedangkan sisanya sebanyak 8,02\% melakukan bisnis. Hal ini menunjukkan bahwa hampir 100\% wisatawan mancanegara memang menganggap Pulau Bali sebagai lokasi berlibur dengan aktivitas wisata yang beraneka ragam sesuai dengan minat wisatawan. 


\section{Frekuensi Kunjungan ke Klinik Radiance, Bali}

Berdasarkan hasil olahan data statistik dari 200 sampel wisatawan mancanegara, sebanyak 114 wisatawan mancanegara atau setara dengan 53,77\% mengaku baru pertama kali melakukan layanan medis di klinik radiance. Sisanya, 46,23\% mengaku sudah lebih dari sekali mendapatkan layanan medis di Klinik Radiance.

\section{Hasil Uji Validitas dan Reliabilitas Model Pengukuran}

Artikel ini menguji validitas dan reliabilitas dari ketiga variabel konstruk yang dipilih yaitu kualitas layanan, kepuasan wisatawan medis, dan loyalitas wisatawan medis seperti yang tercantum dibawah ini.

Unidimensionalitas Model Pengukuran Variabel Laten

Nilai loading factor yang memenuhi syarat dalam unidimensionalitas variabel laten adalah $>0,5$. Oleh karena itu, nilai yang menunjukkan diatas 0,5 akan dinyatakan valid dan dapat dianalisis lebih lanjut.

Tabel 4. Loading Factor Konstruk Laten

\begin{tabular}{lllc}
\hline & & & Estimate \\
\hline SQ2 & $<---$ & SERV_QUAL &, 585 \\
SQ3 & $<---$ & SERV_QUAL &, 922 \\
SQ4 & $<---$ & SERV_QUAL &, 755 \\
SQ5 & $<---$ & SERV_QUAL &, 695 \\
SQ6 & $<---$ & SERV QUAL &, 829 \\
SQ7 & $<---$ & SERV_QUAL &, 716 \\
SAT1 & $<---$ & SATISFACTION &, 563 \\
SAT2 & $<---$ & SATISFACTION &, 829 \\
SAT3 & $<---$ & SATISFACTION &, 695 \\
SAT4 & $<---$ & SATISFACTION &, 840 \\
SAT5 & $<---$ & SATISFACTION &, 591 \\
\hline
\end{tabular}




\begin{tabular}{lllr}
\hline LOY1 & $<---$ & LOYALTY &, 857 \\
\hline LOY2 & $<---$ & LOYALTY &, 795 \\
LOY3 & $<---$ & LOYALTY &, 818 \\
LOY4 & $<---$ & LOYALTY &, 795 \\
LOY5 & $<---$ & LOYALTY &, 888 \\
\hline
\end{tabular}

Sumber:

Hasil Olahan Amos, 2018

Berdasarkan hasil tabel loading factor atau standardized regression weights, maka seluruh nilai loading factor penyusun kualitas layanan medis, kepuasan wisatawan, dan loyalitas wisatawan berada di atas nilai 0,5 sehingga dapat dikatakan semua indikator pada konstruk kualitas layanan, kepuasan wisatawan, dan loyalitas wisatawan telah memenuhi nilai persyaratan.

\section{Validitas Model Pengukuran Konstruk Kualitas Layanan Medis}

Validitas konstruk terdiri dari validitas konvergen dan validitas konstruk. Validitas konvergen dapat dilihat dari nilai probabilitas pada tabel regression weights dengan syarat nilai probabilitas harus dibawah dari 0,05. Setelah itu, validitas konstruk dapat dilihat dengan nilai kriteria goodness of fit yang dipersyaratkan. Berikut diuraikan masing-masing validitas konstruk kualitas layanan medis:

1) Validitas Konvergen

Validitas konvergen untuk konstruk kualitas layanan medis dapat dilihat dari hasil analisis data pada tabel dibawah ini: 
Tabel 5. Regression Weights: Konstruk Laten

\begin{tabular}{|c|c|c|c|c|c|c|}
\hline & & & Estimate & S.E. & C.R. & $\mathbf{P}$ \\
\hline SQ2 & $<--$ & SERV_QUAL & 692 & ,076 & 9,054 & $* * *$ \\
\hline SQ3 & $<--$ & SERV_QUAL & 1,000 & & & \\
\hline SQ4 & $<--$ & SERV_QUAL & ,974 & ,076 & 12,763 & $* * *$ \\
\hline SQ5 & $<--$ & SERV_QUAL & ,920 & ,083 & 11,127 & $* * *$ \\
\hline SQ6 & $<--$ & SERV_QUAL & 1,050 & ,073 & 14,420 & $* * *$ \\
\hline SQ7 & $<--$ & SERV_QUAL & 753 & ,064 & 11,747 & $* * *$ \\
\hline SAT1 & $<--$ & SATISFACTION & 1,000 & & & \\
\hline SAT2 & $<--$ & SATISFACTION & 1,545 & 194 & 7,957 & $* * *$ \\
\hline SAT3 & $<--$ & SATISFACTION & 1,033 & ,142 & 7,276 & $* * *$ \\
\hline SAT4 & $<--$ & SATISFACTION & 1,218 & 153 & 7,975 & $* * *$ \\
\hline SAT5 & $<--$ & SATISFACTION & 1,082 & , 169 & 6,404 & $* * *$ \\
\hline LOY1 & $<--$ & LOYALTY & 1,000 & & & \\
\hline LOY2 & $<--$ & LOYALTY & 1,000 & & & $* * *$ \\
\hline LOY3 & $<--$ & LOYALTY & ,979 & ,072 & 13,503 & $* * *$ \\
\hline LOY4 & $<--$ & LOYALTY & 1,065 & ,076 & 14,092 & $* * *$ \\
\hline LOY5 & $<--$ & LOYALTY & 1,095 & ,080 & 13,637 & $* * *$ \\
\hline
\end{tabular}

(Ket: Tanda ${ }^{* * *}$ berarti nilai $\left.\mathrm{P}<0,05\right)$, Sumber: Hasil Olahan AMOS 2018

Dari Tabel 5 dapat dinyatakan bahwa semua nilai P (probability) probabilitas konstruk kualitas layanan, kepuasan, dan loyalitas wisatawan dinyatakan baik karena berada dibawah 0,05 .

2) Validitas Konstruk

Validitas Konstruk digunakan untuk mengetahui goodness of fit ketiga konstruk yang menjadi variabel dalam artikel ini yaitu kualitas layanan medis, kepuasan wisatawan, dan loyalitas wisatawan. Berikut merupakan hasil dari validitas konstruk (goodness of fit) dari ketiga konstruk laten dalam artikel ini:

Tabel 6. Hasil Persyaratan Uji Goodness of Fit Modifikasi Tiga Konstruk Latem 


\begin{tabular}{|c|c|c|c|c|c|}
\hline $\begin{array}{l}\text { Goodness of fit } \\
\text { Indeks }\end{array}$ & $\begin{array}{l}\text { Nilai } \\
\text { Persyaratan }\end{array}$ & Hasil SQ & Hasil SAT & $\begin{array}{l}\text { Hasil } \\
\text { LOY }\end{array}$ & Keterangan \\
\hline Chisq & $<23,68$ & 5,95 & 2,79 & 9,96 & Baik \\
\hline Chisq/df & $<2,0$ & 0,85 & 0.59 & 0,76 & Baik \\
\hline GFI & $\geq 0,90$ & 0,99 & 0,99 & 0,98 & Baik \\
\hline AGFI & $\geq 0,90$ & 0,97 & 0,97 & 0,93 & Baik \\
\hline CFI & $\geq 0,90$ & 1,00 & 1,01 & 0,99 & Baik \\
\hline RMSEA & $<0,08$ & 0,00 & 0,00 & 0,07 & Baik \\
\hline
\end{tabular}

Sumber: Hasil Olahan AMOS, 2018

Berdasarkan hasil dari validitas konvergen dan validitas konstruk yang telah dianalisis maka dapat disimpulkan bahwa seluruh indikator pembentuk kualitas layanan, kepuasan wisatawan, dan loyalitas wisatawan dinyatakan valid, sehingga dapat digunakan untuk analisis selanjutnya.

c. Kehandalan (Reliabilitas) Model Pengukuran Kualitas Layanan Medis

Kehandalan model pengukuran terdiri dari kehandalan internal, kehandalan konstruk dan Average Variance Extracted (AVE). Kehandalan internal tercapai ketika nilai Cronbach Alpha $\geq 0,70$. Kehandalan konstruk diperoleh jika nilai CR melebihi $\geq 0,5$. AVE diperoleh dari persentasi rata-rata dari varians yang dijelaskan oleh item dalam konstruk dengan syarat $\geq 0,5$. Berikut adalah hasil uji kehandalan.

Tabel 7. Hasil Uji Kehandalan 3 Variabel Laten

\begin{tabular}{|l|l|l|l|l|l|}
\hline Kehandalan Model & Nilai Persyaratan & Hasil SQ & Hasil SAT & Hasil LOY & Keterangan \\
\hline $\begin{array}{l}\text { Kehandalan } \\
\text { Internal }\end{array}$ & $\geq 0,70$ & 0,88 & 0,87 & 0,88 & Baik \\
\hline $\begin{array}{l}\text { Kehandalan } \\
\text { Konstruk }\end{array}$ & $\geq 0,5$ & 0,89 & 0,85 & 0,91 & Baik \\
\hline AVE & $\geq 0,5$ & 0,57 & 0,54 & 0,67 & Baik \\
\hline
\end{tabular}

Sumber: Hasil Olahan AMOS, 2018 
Berdasarkan hasil uji kehandalan yang dilakukan pada Tabel 7, maka secara keseluruhan kontruk kualitas layanan, kepuasan, dan loyalitas dinyatakan memiliki kehandalan yang baik, sehingga dapat digunakan pada analisis selanjutnya.

d. Uji Normalitas

Dalam artikel ini, uji normalitas digunakan untuk mengetahui distribusi yang baik melalui nilai Skewness dan kurtosis pada seluruh konstruk. Berikut adalah hasilnya.

Tabel 8. Hasil Uji Normalitas Tiga Variabel Laten

\begin{tabular}{|c|c|c|c|c|c|c|c|c|c|c|c|c|c|c|c|c|c|c|c|}
\hline & & sQ. & 902 & S0.3 & 204 & 30,5 & 926 & 307 & 303 & $5: 1$ & 512 & st? 3 & $5: 4$ & $\$ 5$ & lyy & 182 & $\mathrm{LY}_{3}$ & 484 & Lys \\
\hline \multirow[t]{2}{*}{$\bar{N}$} & 霜 & $\bar{w}$ & 200 & $\overline{8}$ & 200 & $\overline{20}$ & 20 & 20 & $2 m$ & $\overline{200}$ & 28 & 20 & $\bar{W}$ & 20 & 80 & 2 & $\overline{2010}$ & 28 & $\overline{200}$ \\
\hline & Wang & 8 & 0 & 8 & 0 & 0 & 0 & D & 8 & 0 & $\theta$ & 0 & 0 & 0 & 0 & 0 & 0 & 0 & 0 \\
\hline \multicolumn{2}{|c|}{ SM Deowh } & 022645 & 026 & 12244 & 0,25017 & 02285 & 0,2813 & 224666 & $0.25 \%$ & 0,2650 & 0.2443 & 0,2164 & 02667 & 0,2466 & Q2006 & (22201] & 022513 & 0.2644 & 023515 \\
\hline \multicolumn{2}{|c|}{ veroo } & 0.156 & 0,061 & Q.65 & 0,063 & 0,054 & $0,0 \%$ & 2062 & 0,055 & 0,050 & 0.555 & DONG & 0063 & 0,285 & OES2 & 0,062 & 0,156 & 0,010 & 0.050 \\
\hline \multicolumn{2}{|c|}{ Sterren } & till & .1840 & $-1, \pi$ & $-1,814$ & +1088 & $-1,73$ & 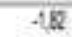 & $-1,716$ & 4,82 & $-1,765$ & -15200 & .1978 & $4,2 \mathrm{DM}$ & 468 & $-1,5865$ & +100 & $-1,797$ & 4,873 \\
\hline \multicolumn{2}{|c|}{ Sid Exu d Senvas } & 0.172 & 0.172 & Q.172 & 0.72 & 0.172 & 0.172 & 0172 & Q.572 & 0,12 & 0.172 & 0,12 & 0.172 & 8,12 & 2,172 & Q.172 & 0,172 & 0,172 & 0,12 \\
\hline \multicolumn{2}{|c|}{ Kenss } & 1,186 & 1,20 & 1, 20 & 1.804 & $\sqrt{6}$ & 1,500 & ve & 1,39 & 3,500 & 1,466 & 0,74 & 1458 & 1,975 & 126 & 0,83 & 1,8 & 1,395 & $1, \pi 00$ \\
\hline \multicolumn{2}{|c|}{ 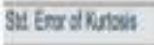 } & 0.42 & 0,36 & 0.42 & 0,362 & 0.42 & 0,39 & 2.342 & 0,342 & 0,82 & 0.42 & 0,36 & 0342 & 0,38 & $0 \$ 2$ & 0,392 & 0342 & 0,34 & 0,502 \\
\hline \multicolumn{2}{|c|}{ Purge } & 0,8 & 0.8 & Q8 & 68 & ab & 08 & $Q B$ & 0,2 & 88 & 0.8 & 28 & 08 & 0.8 & 0.8 & 0.8 & $A B$ & 08 & 28 \\
\hline
\end{tabular}

Sumber: Hasil Olahan SPSS, 2018

Setelah dilakukan pengecekan pada Tabel 8, maka seluruh data pada seluruh konstruk terdistribusi normal. Hal ini terlihat dari nilai skewness dan kurtosis diantara -2 dan 2 menurut George \& Mallery (2010).

\section{Model Struktural Akhir}

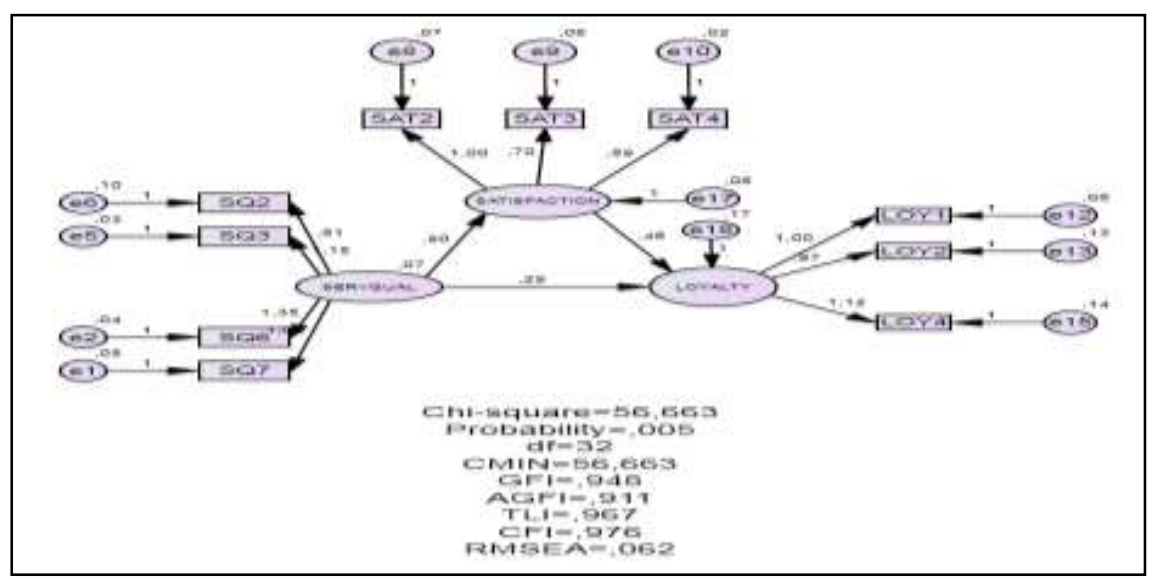

Gambar 1. Model Struktural Akhir

Sumber : Hasil Olahan AMOS (2018) 
Setelah melakukan uji validititas dan kehandalan konstruk, maka ketiga model dalam konstruk laten disatukan. Berdasarkan saran dari AMOS, maka modifikasi terjadi pada konstruk SERV_QUAL (kualitas layanan) dan SATISFACTION (kepuasan wisatawan). Langkah selanjutnya adalah melakukan pengecekan kembali syarat-syarat goodness of fit seperti berikut:

Tabel 9. Goodness of fit Model Struktural Akhir

\begin{tabular}{llll}
\hline Goodness of fit Indeks & Nilai Persyaratan & Hasil Analisis & Keterangan \\
\hline Chi-Square X2 & $\leq 233,99$ & 56,66 & Baik \\
\hline Level of Probability & $\geq 0,05$ & 0,05 & Baik \\
\hline Degree of Freedom & Positive & 32 & Baik \\
\hline CMIN/DF & $\leq 3$ & 1,7 & Baik \\
\hline GFI & $\geq 0,90$ & 0,94 & Baik \\
\hline AGFI & $\geq 0,80$ & 0,91 & Baik \\
\hline NFI & $\geq 0,90$ & 0,94 & Baik \\
\hline TLI & $\geq 0,90$ & 0,96 & Baik \\
\hline CFI & $\geq 0,90$ & 0,97 & Baik \\
\hline RMSEA & $\leq 0,08$ & 0,06 & Baik \\
\hline
\end{tabular}

Sumber: Hasil Olahan AMOS 2018

Tabel 9 menggambarkan evaluasi GoF dari model akhir setelah dilakukan modifikasi. Dari hasil uji full model, yang terpenting adalah nilai Chi-square harus dalam kategori "Baik" (dibawah nilai yang dipersyaratkan yaitu < 233,99). Jika indeks lainnya terpenuhi, berarti data semakin fit dengan model. Sehingga lebih lanjut dapat digunakan untuk pengujian hipotesis.

\section{Pengujian Hipotesis}

Hasil uji hipotesis dipaparkan dalam tabel dan penjelasan dibawah ini. 
Tabel 10. Standardized Regression Weights Model SEM Tiga Konstruk Laten

\begin{tabular}{|llll|lll|}
\hline Hipotesis & \multirow{2}{*}{ Konstruk } & & $\begin{array}{l}\text { Std- } \\
\text { ize }\end{array}$ & P-Value & Ket \\
\hline H1 & SATISFACTIO & $<--$ & SERVICEQUALITY &, 725 & 0,000 & Sig \\
& $\mathrm{N}$ & & & & Sig \\
H2 & LOYALTY & $<---$ & SATISFACTION &, 576 & 0,000 & Sig \\
H3 & LOYALTY & $<---$ & SERVICEQUALITY &, 246 & 0,016 & \\
\hline
\end{tabular}

Sumber: Hasil Olahan AMOS 2018

1. Kualitas pelayanan medis berpengaruh positif dan signifikan terhadap kepuasan wisatawan mancanegara di Klinik Radiance, Kuta, Bali diterima dengan koefisien 0,725 dan $p$ value 0,000 .

2. Kepuasan wisatawan mancanegara berpengaruh positif dan signifikan terhadap loyalitas wisatawan mancanegara di Klinik Radiance, Kuta, Bali diterima dengan koefisien sebesar 0,576 dan p value 0,000.

3. Kualitas layanan medis berpengaruh positif dan signifikan terhadap loyalitas wisatawan mancanegara pada Klinik Radiance, Kuta, Bali diterima dengan koefisien sebesar 0,246 dan p value 0,016.

\section{Pembahasan}

Setelah dijelaskan mengenai karakteristik wisatawan asing, pengujian validitas, kehandalan, dan hipotesis artikel ini. Selanjutnya pembahasan mengenai hubungan antar variabel dalam artikel ini yaitu kualitas layanan, kepuasan wisatawan, dan loyalitas wisatawan akan dijelaskan berikut ini 


\section{Pengaruh Langsung Kualitas Layanan Medis Terhadap Kepuasan Wisatawan}

Kualitas Layanan memiliki pengaruh langsung, positif dan signifikan terhadap kepuasan wisatawan mancanegara. Berdasarkan hasil tersebut, aspek kualitas layanan medis yang berkualitas akan memberikan kepuasan bagi wisatawan mancanegara yang sedang berkunjung melakukan wisata medis. Hasil penelitian ini mengkonfirmasi hasil penelitian Debata, 2013. Dimana dalam penelitian itu disebutkan bahwa penting adanya mengukur kepuasan wisatawan pada aspek kualitas pelayanan untuk mengetahui puas tidaknya wisatawan mancanegara terhadap pelayanan medis secara keseluruhan dalam rangka meningkatkan kualitas wisata medis di Bali secara keseluruhan.

Apabila dilihat dari masing-masing dalam keenam indikator tersebut, maka didapatkan indikator ketiga atau keramahan lah yang memiliki nilai paling tinggi. Penetapan keramahan menjadi indikator dalam kualitas layanan medis yang memberikan kepuasan paling tinggi kepada wisatawan mancanegara sangat sesuai dengan data dan fakta yang ditemukan di Klinik Radiance Bali. Fakta bahwa mulai bermunculan layanan wisata medis di Bali berbasis perawatan kulit dan wajah membuat persaingan semakin ketat. Selama melakukan penelitian dan pengambilan data di Klinik Radiance, hal yang paling diutamakan oleh pemilik Klinik Radiance adalah keramahan kepada klien. Seluruh staff klinik Radiance memberikan pelayanan yang baik dengan ramah kepada setiap pelanggan. Mereka semua mampu menggunakan bahasa Inggris dengan baik sehingga seluruh informasi dapat diterima dengan baik oleh pasien wisatawan mancanegara. Staff klinik Radiance bahkan kerap kali bercanda dengan wisatawan mancanegara untuk menghilangkan efek mengerikan ketika melakukan perawatan medis, sehingga pasien nyaman ketika melakukan perawatan. 


\section{Pengaruh Langsung Kepuasan Wisatawan Terhadap Loyalitas Wisatawan}

Dalam penelitian ini, terdapat pengaruh langsung antara variabel kepuasan wisatawan dan loyalitas wisatawan. Pengaruh tersebut positif dan signifikan dimana kepuasan wisatawan berperan sebagai variabel intervening. Variabel ini terdiri dari lima indikator yaitu, kepuasan memilih, kepuasan aktivitas, kepuasan pengalaman, kepuasan nilai, serta kepuasan menyeluruh. Mengacu pada hasil analisis, tingkat kepuasan yang tinggi akan menyebabkan tingginya loyalitas wisatawan di Klinik Radiance Bali. Sebaliknya, bila wisatawan tidak puas maka loyalitas wisatawan pun akan menurun. Hasil penelitian ini mengkonfirmasi penelitian sebelumnya milik Yoon dan Uysal (2005) serta Lee dan Liu (2009) di mana kepuasan memiliki peran penting dan kuat dalam mempengaruhi loyalitas.

Tingkat kepuasan wisatawan yang terbentuk mampu mempengaruhi loyalitas wisatawan terhadap Klinik Radiance Bali. Hal ini ditunjukkan dengan jumlah wisatawan mancanegara yang melakukan revisit layanan medis di Klinik Radiance yang berjumlah hampir 50\% dari total responden yang dimintai keterangan. Senada dengan hal ini, penemuan Boit J. C. (2013) menunjukkan hasil yang sama melalui analisis regresi linier yaitu hubungan positif dan signifikan antara kepuasan wisatawan dan loyalitasnya.

\section{Loyalitas Wisatawan Mancanegara Terhadap Kualitas Wisata Medis Bali}

Pada bagian ini akan dibahas mengenai pengaruh tidak langsung antara kualitas layanan medis dan loyalitas. Artikel ini mengukur loyalitas dengan lima item indikator, yaitu keinginan untuk mau mencoba lagi, menjadikan klinik pilihan utama, keinginan untuk kembali, berlangganan, dan merekomendasikan. Mengacu pada hasil olahan data, variabel kualitas layanan memiliki pengaruh positif dan signifikan terhadap loyalitas wisatawan yang pernah berkunjung ke Klinik Radiance, Bali. 
Indikator paling tinggi dalam loyalitas wisatawan adalah keinginan untuk mencoba lagi. Artinya, wisatawan mancanegara baik yang sudah pernah melakukan layanan medis di Klinik Radiance, maupun yang baru pertama menerima layanan medis di klinik Radiance, memiliki keinginan kembali lagi. Hal ini ditunjukkan terutama dalam pembahasan karakteristik responden sebelumnya. Dari hasil pengumpulan data, sebanyak $53,77 \%$ pasien wisatawan merupakan pasien yang baru pertama kali melakukan layanan medis, artinya sekitar 46,23\% merupakan wisatawan yang sudah lebih dari sekali melakukan layanan medis di Klinik Radiance. Jumlah revisit yang hampir menyentuh angka 50\% menunjukkan bahwa loyalitas wisatawan ke Klinik Radiance merupakan peluang besar bagi perkembangan wisata medis di Indonesia terutama di Bali.

\section{Simpulan dan Saran}

Artikel ini berusaha untuk menggambarkan hubungan antara kualitas layanan, kepuasan, dan loyalitas wisatawan. Berdasarkan analisis data menggunakan bantuan AMOS versi 24, terdapat tiga pengaruh kualitas layanan, kepuasan, dan loyalitas. Hubungan pertama terbentuk antara kualitas layanan terhadap kepuasan wisatawan. Dimana terdapat pengaruh langsung, positif dan signifikan. Pengaruh tersebut menunjukkan bahwa semakin baik kualitas layanan medis di Klinik Radiance, maka kepuasan wisatawan mancanegara akan semakin tinggi dengan keramahan sebagai indikator yang paling penting dalam meningkatkan kepuasan wisatawan. Kedua, adalah hubungan antara kepuasan wisatawan dan loyalitas wisatawan yang memiliki pengaruh langsung, positif, dan signifikan. Hubungan menggambarkan bahwa semakin tinggi tingkat kepuasan, maka akan semakin tinggi loyalitasnya dimana kepuasan terhadap nilai merupakan indikator yang paling tinggi menyebabkan loyalitas wisatawan mancanegara. Ketiga, terdapat hubungan tidak langsung, positif, dan signifikan antara kualitas layanan dan loyalitas wisatawan mancanegara. Artinya, semakin baik kualitas 367 JUMPA Volume 05, Nomor 02, Januari 2019 
layanan medis maka akan meningkat loyalitas wisatawan. Namun, adanya pengaruh tidak langsung berarti bahwa hubungan kualitas dan loyalitas tidak akan terjadi bila tidak melalui variabel intervening atau kepuasan terlebih dahulu.

Berdasarkan hasil penelitian ini, maka seluruh indikator dapat menjelaskan variabel latennya masing-masing dengan baik terlihat dari uji validitas dan reliabilitasnya. Oleh karena itu, indikator dalam kualitas layanan, kepuasan, dan loyalitas wisatawan, harus selalu dipertahankan dan ditingkatkan.

\section{Daftar Pustaka}

Aryani, D, Rosinta, F., 2010. Pengaruh kualitas Layanan Terhadap Kepuasan Pelanggan Dalam Membentuk Loyalitas Pelanggan. Jurnal Ilmu Administrasi dan Organisasi.Vol.17.No.2.

Baker, D. A. Crompton, J. L., 2000. Quality, satisfaction and behavioral intentions. Annals of tourism research, 27(3), 785-804. http://dx.doi.org/10.1016/S01607383(99)00108-5.

Bigne, J. E., Sanchez, M. I. Sanchez, J., 2001. Tourism image, evaluation variables and after purchase behaviour: inter-relationship. Tourism management, 22(6), 607616. http://dx.doi.org/10.1016/S0261-5177(01)00035-8.

Boit, J. C., 2013. The role of destination attributes and visitor satisfaction on tourist repeat visit intentions toLake Nakuru National Park, Kenya. Western Iliinois.

Caruana, A., 2002. "Service Loyalty: The Effects Of Service Quality And The Mediating Role Of Customer Satisfaction", European Journal of Marketing, Vol. 36 Issue: 7/8, pp.811-828,

Carrera, P. M. Bridges, F. P., 2006. Globalization and healthcare: Understanding health care and medical tourism. Expert Review of Pharmacoeconomics and Outcomes Research, 6, 447-454.

Connell, J. 2006. Medical tourism: Sea, sun, sand and ... surgery. Tourism, Management, 27(6), 1093-1100.

Debata, B.R. Patnaik, B., Mahapatra, S.S. Sreekumar, 2013. Interrelations of Service Quality and Service Loyalty Dimensions in Medical Tourism: A Structural Equation Modelling Approach, Emerald Insight Journal, India.

Garcia-Altes, "The Development of Health Tourism Services," Annals of Tourism Research, Vol. 32, No. 1, 2005, pp. 262-266. 
George, D. Mallery, P., 2010. SPSS for Windows Step by Step A Simple Guide and Reference 17.0 Update. 10th Edition, Pearson, Boston.

Hair, J. F. Black, W. C. Babin, B. J. Anderson, R. E. 2010, Multivariate Data Analysis 7th Edition. Pearson Prentice Hall.

Horowitz, M.D. Rosensweig, J.A. 2007. Medical Tourism-Health Care In The Global Economy. The Physician Executive, 12, 24-30.

Kementerian Pariwisata RI. 2017. Laporan Kinerja KEMENPAR RI, Maret, diakses pada:

http://kemenpar.go.id/userfiles/LAPORAN\%20KINERJA\%20KEMENPAR\%2 02016_FINAL.pdf

Kotler, Philip. 2005. Manajemen Pemasaran Jilid 1 (11th ed.)(Benyamin Molan, Penerjemah). Jakarta: PT. Indeks.

Kozak, M. Rimmington M., 1999. 'Measuring Tourist Destination Competitiveness: Conceptual Consideretions, And Empirical Findings,' International Journal of Hospitaly Management, Vol 18 no3 pp 273-283.

Kumar, M. Kee, F. T. Manshor, A. T., 2009. Determining the relative importance of critical factors in delivering service quality of banks; An application of dominance analysis in SERVQUAL model, Managing Service Quality, Vol. 19, Number 2, p. 211-228 .

Lee, H. Liu, C., 2009. The relationship among achievement motivation, psychological contract and work attitudes. Social Behavior and Personality: An international journal, 37, 321-328.

Lupiyoadi, R \& Hamdani, A. 2006. Manajemen Pemasaran Jasa. Jakarta: Salemba Empat.

Parasuraman, A., Zeithaml, V. A., \& Berry, L. L. (1988). SERVQUAL: A Multiple-Item Scale For Measuring Consumer Perceptions Of Service Quality, Journal of Retailing, Vol. 64, Number 1, p.12-40.

Pidada, I.B.U., 2018. Tingkat Kepuasan Wisatawan Mancanegara Terhadap Kualitas Pelayanan Rekreasi Air PT Pandawa Marine Adventures di Tanjung Benoa, JUMPA, Vol 05, No. 01 Page 77-90.

Singh, N. 2014. Healthcare Tourism: An Emerging Concept, International Journal of Management Research and Review. India: Kurukshetra University.

Smith, M. Puczko, L. 2008. Health and wellness tourism. USA: Elsevier Science \& Technology Books.

Wijayanti, N. Evi, P., 2017, Perspektif Wisatawan Domestik Terhadap Kualitas Pelayanan Wisata Arung Jeram Di Sungau Ayung, Bali. JUMPA. Vol 3 Nomor 2 Page 271-283 
Yoon, Y. Uysal, M. 2005. An Examination of the Effects of Motivation and Satisfaction on Destination Loyalty: A Structural Model.Tourism Management, $26,45-56$.

\section{Profil Penulis}

Yudha Eka Nugraha, S. Kesos., M. Par. adalah alumnus Magister Pariwisata Universitas Udayana, Denpasar. Ia menyelesaikan program S1 Kesejahteraan Sosial Universitas Indonesia, Depok pada tahun 2014. Saat ini Yudha adalah tenaga pengajar di Politeknik Internasional Bali.

Syamsul Alam Paturusi adalah Guru Besar Perancangan Kota pada Jurusan Arsitektur, Fakultas Teknik Unud. Saat ini beliau menjabat sebagai Ketua Program Studi S2 Lingkungan. Beliau aktif sebagai dosen pada S2-S3 Ilmu lingkungan, Unud. Beliau adalah lulusan Sarjana (S1) di Universitas Hasanuddin, Makassar, Magister (S2) di PWK ITB, Bandung, dan Doktor (S3) di Université de Pau et des Pays de l'Adour, Perancis.

NMS Wijaya (Ni Made Sofia Wijaya) menamatkan pendidikan Diploma IV di Universitas Udayana Denpasar pada tahun 2003. Pada tahun 2007-2009, ia mengikuti Program Pascasarjana Universitas Udayana, Denpasar. Di tahun 2007, Ia mengikuti short course program International Degree Program in Tourism Management (ISTM) di University Apllied Sciences, Hochschule, Bremen. Menyelesaikan studi di Program Doktor di Yamaguchi University, Jepang dan kini menjadi salah satu dosen pengajar di Fakultas Pariwisata Universitas Udayana Denpasar. 